\title{
Hazards on the homestretch in Washington's push to extend health care to millions
}

Published at www.cmaj.ca on Jan. 6, 2010

$\mathrm{F}$ ew quarrel with United States President Barack Obama anymore when he says health reform is a matter of when, not if. The question that persists, though, after a year of rising expectations capped by a marathon winter debate, is how farreaching it will be.

Legislators have a messy task ahead of them before history can record a sea change in American health care. Confronting them are two pieces of health reform legislation that have been respectively passed by the two arms of Congress, each of epic length and containing sticky differences that must be reconciled before Obama can claim success where so many presidents have failed.

In Washington, DC, that legislative process is known formally as reconciliation and informally as sausage-making, meaning not pretty to watch and likely to feature as much deal making as the fractious debate surrounding passage of the Senate bill (CMAJ 2009. DOI:10 .1503/cmaj.109-3132).

But the Senate bill and one passed earlier by the House of Representatives must be melded into common legislation for both chambers to pass and for Obama to sign before it can become law.

This is where it gets messy.

The House bill is more ambitious, more expensive and reaches an estimated six million more uninsured people. But senators have signaled they have little room left to compromise and the final product will have to look closely like their more limited package.

The House bill also proposes a government-run insurance plan to compete in the private marketplace, a non-starter in the Senate. It also proposes to obligate medium and large employers to provide insurance for employees, missing in the Senate bill, as well as to

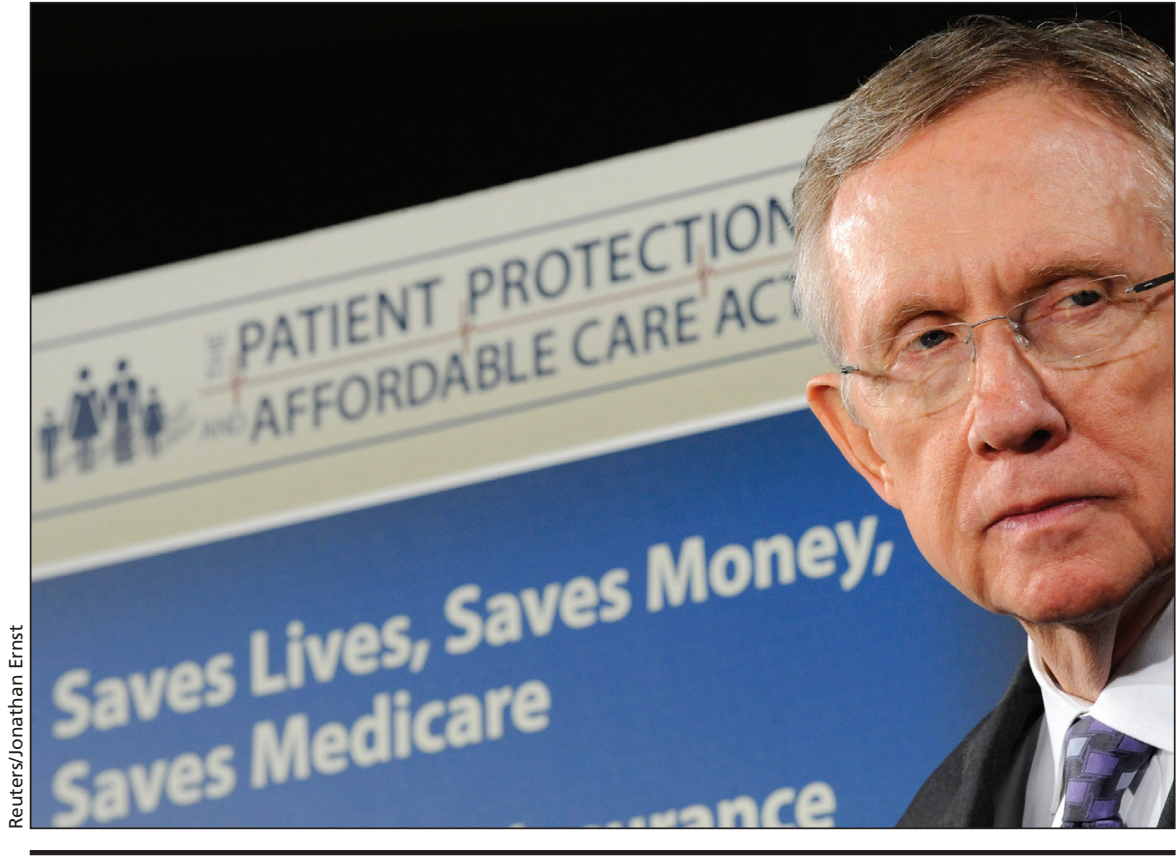

United States Senate Majority Leader Harry Reid (Democrat-Nevada) addresses Senate health care legislation at a news conference in December 2009.

require many of the benefits to start in 2013, as opposed to 2014.

All of that and much more must somehow be reconciled, preferably before Obama delivers his State of the Union speech to Congress on Jan. 27.

Obama was barely in office a month when he went before a joint session of Congress and promised to deliver on an issue that has proved a dead end, if not a political fool's errand, for past leaders. "Nearly a century after Teddy Roosevelt first called for reform, the cost of our health care has weighed down our economy and the conscience of our nation long enough," Obama declared in that February 2009 address. "So let there be no doubt: Health care reform cannot wait, it must not wait, and it will not wait another year."

That year is about up.

Compromises made in the Senate bill, essential to winning the 60 votes needed for passage, split the political left. Speaking for dismayed liberals,
Howard Dean, former Democratic Party chairman, said the changes are so limited they are worse than nothing. But former president Bill Clinton, whose more far-reaching reforms met failure, dubbed the effort a vital start. "America can't afford to let the perfect be the enemy of the good."

Ron Pollack, executive director of the consumer advocacy group Families USA, concurs. "This is a huge step," he says. "Reform will extend coverage to the vast majority of people who are uncovered today. It will radically transform insurance industry practices" and bring peace of mind to workers who have always had to worry about losing insurance when they lose or change jobs.

A public insurance option, Pollack adds, "never was a likely outcome of this debate."

That's largely because a public plan is viewed as a step too far for a country that has resistance to expansive govern- 
ment locked in its DNA (CMAJ 2009: DOI:10.1503/cmaj.109-3027).

Whatever the outcome of reconciliation, it will hardly be universal health care although both bills would require nearly all Americans to get health insurance, penalize those who don't and provide substantial subsidies to families making up to US\$88 000 .

Insurance company practices that expose patients to staggering medical bills would be banned. No longer could insurers deny coverage to people with existing illnesses, charge them more than other policyholders or make older people pay prohibitively higher rates than the young.

Still, the Senate bill would leave as many as 24 million, and the House bill
18 million, uninsured - primarily illegal immigrants.

Most subsidies and insurance protections would take three or four years to kick in, although the taxes to help pay for them would start sooner.

Some changes would apply immediately. Young people could stay on their parents' insurance through age 26 . Insurance companies would be quickly banned from rescinding a policyholder's existing coverage under most circumstances or from applying a lifetime cap on benefits.

The Senate and House must also settle their differences over abortion coverage and over how to pay for health reform. The Senate proposes a hefty tax penalty on "Cadillac insurance plans," which cost families more than US\$23 000 a year. The House objects, saying it might hurt not just fat-cat executives but union members with hard-won, high-value plans. The Senate plan's estimated cost: US $\$ 871$ billion over 10 years. The House plan tops $\$ 1$ trillion.

Democrats, who control both houses of Congress, favor a reconciliation process that would see House and Senate lawmakers informally negotiate their differences. Another option: a formal conference committee with representation from both Congressional arms. - Cal Woodward, Washington, DC

DOI:10.1503/cmaj.109-3148 